\title{
The Development Strategies on the Batik Creative Industry as an Enthralling Sector for Cultural Tourism in Bondowoso Regency, East Java
}

\author{
Syubbanul Wathon, Rike Oktarianti, Kartika Senjarini \\ Faculty of Mathematics and Natural Sciences, University of Jember \\ senjarini@unej.ac.id
}

\begin{abstract}
The Bondowoso Regency has great potential to evolve into a center for the batik creative industry. However, there are still no batik products that demonstrate the uniqueness of the Bondowoso Regency. Several community groups in Suling Wetan Village, Cermee Subdistrict, Bondowoso Regency, have been running batik businesses as artisans since 2015. The community groups have had the basic skills to produce batik; unfortunately, they still do not give any impact to the growth of the cultural tourism destinations in Bondowoso. The old batik designs do not attract buyers, have limited color combinations, and only rely on synthetic batik dyes. Through the partnership service program that has been implemented, some of the batik community businesses can develop their products. This partnership service program is done by several activities, such as: socialization; workshops on batik design and the use of natural dyes; training on natural materials and batik coloring; procurement of gawangan ${ }^{1}$, pendulum ${ }^{2}$ and accessories; training and mentoring techniques for making interesting batik motifs and coloring using natural dyes; and the dialogue to develop the creative batik industry. The results of this program are to develop not only the Suling Wetan Village but also make the batik community business in Cermee Subdistrict, independently grow as a creative batik industry. These improvements also captivate the cultural tourism in Bondowoso Regency.
\end{abstract}

Keywords: Batik, Creative Industry, Creativity, Cultural Tourism, Innovation.

\section{INTRODUCTION}

The dynamics of the global economy have encouraged various regions to produce output efficiently in order to survive globalization. The existence of high competitiveness is the basis to grow and develop into a superior and advanced area. ${ }^{3}$ Competitiveness that arises not only about quantity but also the value of the quality of the product. The quality of products can be obtained by creating innovative products that have different values from other regions. ${ }^{4}$ The existence of this strategic space makes creative economic efforts develop quickly. ${ }^{5}$

\footnotetext{
${ }^{1}$ Gawangan is a place to attach cloth when making batik

2 Pendulum is a pen for making batik

${ }^{3}$ Prasetyo, P. E. 2016. Dampak Kebijakan Peningkatan Techno-Ekonomy Pada Industri Tekstil Sebagai Upaya Peningkatan Produktivitas Dan Daya Saing Bangsa. Prosiding Seminar Multidisiplin Ilmu Unisbank. $820-828$.

${ }^{4}$ Hartini, S. 2012. Peran Inovasi: Pengembangan Kualitas Produk Dan Kinerja Bisnis. Jurnal Manajemen dan Kewirausahaan. 14(1): $82-88$.

${ }^{5}$ Salman, D. 2010. Rethinking Of Cities, Culture And Tourism Within A Creative Perspective. PASOS. 8(3): 06-16.
} 
Creative economy that is synonymous with creative industries can be grouped into 14 sub-sectors, namely a) advertising, b) architecture, c) art goods market, d) craft, e) design, f) clothing (fashion), g) video and film, h) interactive games, i) music, j) showbiz, k) publishing and printing, l) computer and software, $\mathrm{m}$ ) television and radio (broadcasting), n) research and development, and o) culinary. ${ }^{6}$ The creative industry is an economic sector that does not require large scale production. Unlike the case with the manufacturing industry which is oriented to product quantity, the creative industry is more dependent on the quality of human resources. Today, the creative industry actually emerges more from small and medium industry groups. ${ }^{7}$

During the past decade, the creative industry is believed to be able to make a significant positive contribution to an area. The contribution can be in the form of employment, additional regional income, or regional imaging at the national and international level. ${ }^{8}$ Regional imagery arises when an area becomes famous for creative products that are produced and have their own distinctive values. ${ }^{9}$ In a more general context, imaging regions using creative industries can also be linked to various sectors. Especially when connected with the tourism sector, for example handicraft products, art performances, and food, historic tourist sites and locations are created to support the creative industry to continue to grow. ${ }^{10}$

The development of creative industries in an area requires creative people to develop ideas and produce creative products based on intellectual strength, cultural arts, technology that follows the times and emerges on the basis of dynamic community needs. ${ }^{11}$ Culture-based creative industries and local cultural richness are considered necessary to be developed. This is because the richness of local culture is an important part of identity in the creative industry. In addition, it can also help the cultural continuity without damaging while simultaneously supporting the preservation of culture itself. ${ }^{12}$

Creative industries have intellectual and cultural aspects that are developed through potential studies, both by managers and actors, as well as on products that will be produced. One of the major regional potentials to be developed is the batik creative industry. ${ }^{13}$ Batik has been recognized as part of cultural heritage by UNESCO in 2009

\footnotetext{
${ }^{6}$ Departemen Perdagangan Republik Indonesia. 2009. Studi Industri Kreatif Indonesia. Jakarta: Depdag RI.

7 Fitriana, et al. 2014. Pengembangan Industri Kreatif Di Kota Batu (Studi Tentang Industri Kreatif Sektor Kerajinan Di Kota Batu). Jurnal Administrasi Publik. 2(2): 281 - 286.

${ }^{8}$ Mangifera, L. 2016. Pengembangan Industri Kreatif Produk Batik Tulis Melalui Value Chain Analysis. The $3^{\text {rd }}$ University Reserach Colloqoium. 157 - 166.

9 Diana, et al. 2017. Peran Dan Pengembangan Iindustri Kreatif Dalam Mendukung Pariwisata di Desa Mas dan Desa Peliatan Ubud. Jurnal Analisis Pariwisata. 7(2). 84 - 92.

${ }^{10}$ Damayanti, M. dan Latifah. 2015. Strategi Kota Pekalongan Dalam Pengembanagan Wisata Kreatif Berbasis Industri Batik. Jurnal Pengembangan Kota. 3(2): 100 - 111.

Il Sari, N. 2018. Pengembangan Ekonomi Kreatif Bidang Kerajinan Tradisional Jambi (Studi Kasus : Rengke Suku Anak Dalam). Jurnal Menejemen Terapan dan Keuangan. 7(2): 138 - 148.

${ }^{12}$ Bahren, et al. 2014. Industri Kreatif Berbasis Potensi Seni Dan Sosial Sudaya di Sumatera Barat. Jurnal Ekspresi Seni. 16(1): 133 - 155.

${ }^{13}$ Rini, et al. 2015. Strategi Menciptakan Iklim UKM Pada Industri Kreatif Batik Tulis (Studi pada Dinas Koperasi, Industri, Dan Perdagangan Kabupaten Kediri). Jurnal Administrasi Publik. 3(12): 2012 - 2027.
} 
and has been recognized by the international community as an Indonesian product. ${ }^{14}$ The distribution of batik motifs in Indonesia is quite broad and each region has a special motif. The wealth of batik motifs in Indonesia also increases with the emergence of new motifs that are generally brighter and have a more modern style. ${ }^{15}$ Suling Wetan Village, located in Cermee Subdistrict, Bondowoso Regency has a number of community groups that have pioneered businesses as batik craftsmen but have not yet worked optimally as part of the creative or tourism industries. The development of the creative industry of batik products in the Bondowoso Regency requires a strategy so that the batik industry has superior competitiveness. Batik craftsmen in Suling Wetan Village, who are members of several community groups, have produced batik. However, the batik production business was still underdeveloped, whereas it still faced several obstacles (Figure 1). Seeing such conditions, it will be difficult for these community groups as batik artisans to create creative industries that will compete with other creative industrial products. These obstacles need to be resolved with knowledge and application of technology to develop the batik creative industry in Suling Wetan Village.

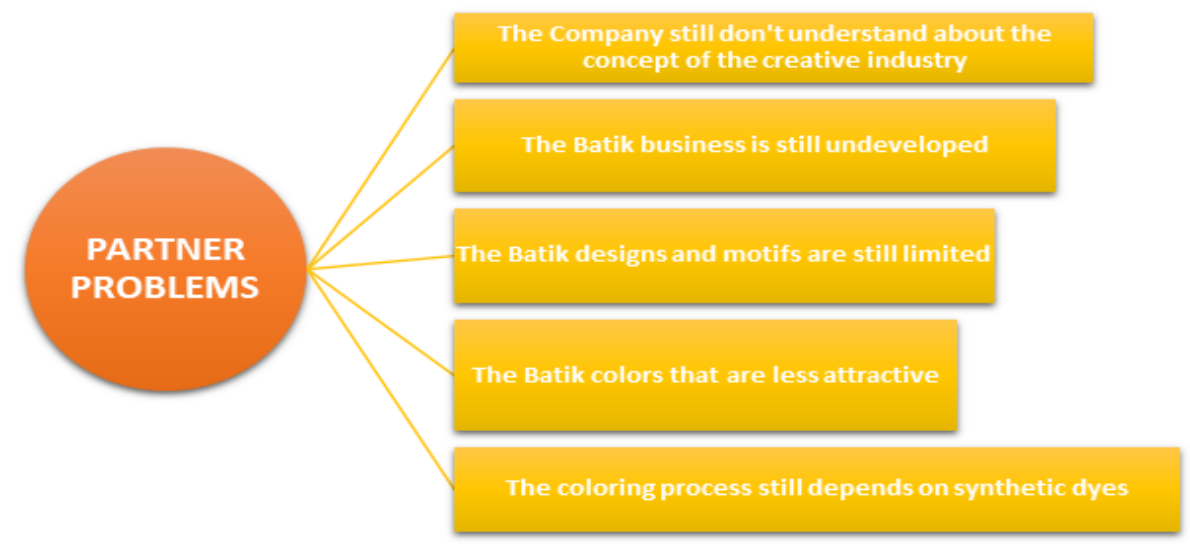

Figure 1. Problems faced by partners

This condition attracted the attention of the academics of the Biology Department, FMIPA at the University of Jember through the Partnership Service Program (PPK) to participate in the community in solving problems faced by batik artisans in Suling Village. The existence of this program is a tangible manifestation of community service activities that are part of the Tri Dharma of Higher Education. The development of the creative batik industry typical of Bondowoso in Suling Wetan Village is expected to increase their income while at the same time opening up new jobs for the surrounding community. Not only that, the success of the development of the Bondowoso Regency's creative batik industry can make Suling Wetan Village a pilot village that can successfully develop and be independent in creating batik creative industries and other creative products. In addition, the development of the batik

\footnotetext{
${ }^{14}$ Lusianti, L. P. dan Rani, F. 2012. Model Diplomasi Indonesia Terhadap UNESCO Dalam Mematenkan Batik Sebagai Budaya Indonesia Tahun 2009. Jurnal Tradisional. 3(2) : 1 - 19.

${ }^{15}$ Nurainun, et al. 2008. Analisis Industri Batik Di Indonesia. Fokus Ekonomi. 7(3): 2124 - 135.
} 
80 | The Development Strategies on Batik Creative Industry as an Enthralling Sector for Cultural Tourism in Bondowoso Regency, East Java

creative industry in Suling Wetan Village can raise the potential of the cultural tourism sector in Bondowoso Regency.

\section{THE IMPLEMENTATION METHODS}

methods used to overcome problems with partners are as follows:

\section{A. Socialization}

The Socialization Program is carried out to convey the intent and purpose of activities by the proposal team to partners. The PPK proposal team explained the background of the KDP program and then designed the equipment and types of training and assistance needed by the partners to achieve the intended target. As a form of reciprocity, partners provide a place for socialization and training, invite fellow activists of similar businesses, and propose experts / speakers who will be invited to complete the training. A series of activities are carried out side-by-side with partners as a form of partner participation in KDP.

\section{B. Provision of business capital Business}

The capital can solve existing problems because it is provided in the form of equipment needed. The PPK proposing team will provide the funds needed to produce batik with modern designs and motifs and equip various other supporting facilities. The proposing team designs and provides these facilities according to the needs of the partners by considering input from partners.

\section{Workshop and Training}

The workshop was conducted to increase partners' knowledge and understanding of the definition, potential, challenges and linkages between batik creative industries and the development of cultural tourism. The training was carried out to improve the ability of partners to create more modern designs of batik motifs and the use of natural batik dyes. The technical use of the equipment is explained in detail until the partners understand and can use it independently. Increased understanding of the making of attractive batik designs and motifs is carried out by bringing in experts on batik design. While increasing partner understanding in using natural batik coloring is done by bringing in speakers in the fields of biology, ethnobotany and batik craftsmen.

\section{Increased understanding}

Improved understanding is done by giving initial knowledge, understanding, and application of the theories that have been given. Theory is given by lecture, discussion and practice methods, using viewer tools, teaching aids and examples needed. Furthermore, an increase in understanding and skills is carried out by measuring foundational knowledge with pre-test and post-test instruments.

\section{E. Mentoring}

The PPK proponent team assists partners in designing motifs and combining batik coloring so that they appear elegant and more modern, using natural batik dyes. Assistance is carried out until partners can implement it independently. Mentoring is 
carried out by supervising the application of the skills provided in theory to ensure that the skills provided are truly implemented in the field.

The economic impact expected from this activity, namely the development of the Bondowoso Regency's creative batik industry, will ultimately increase the income of batik artisans. Regarding the impact on the social sector, this activity can open up new employment opportunities for the community, especially for the younger generation. In addition to social impacts, the impact of the cultural sector is that the development of the batik creative industry has become a driver of the cultural tourism sector in the Bondowoso Regency. The expected impact on the field of science and technology is the transfer of knowledge (technology transfer) between universities and the community.

\section{RESULTS AND PROGRESS ACHIEVED}

Community service programs regarding the strategy of developing the batik creative industry as a driver of the cultural tourism sector district, Bondowoso, have been implemented in Krajan Hamlet, Suling Wetan Village, Cermee District. This Community services is held by done another sub programs including program socialization to partners, preparation of batik design and natural dye training activities, equipment procurement, materials, other equipment for training, workshops and batik design training, the use of natural dyes as well as the discourse of developing the batik creative industry as a driver of the cultural tourism sector in Bondowoso Regency, East Java.

\section{A. Program Socialization for Partners}

The implementation team of the service program has socialized the three partners. The location of the socialization took place at one of the partner posts. The socialization activities are filled with the presentation of programs that will be provided by the service delivery team to partners. Then, proceeding, there is a joint discussion about the plans that will be carried out to realize the program that will be implemented. Partners seem very enthusiastic and cooperative during the socialization activities. This can be seen from several questions, input and suggestions submitted by partner members to the service implementation team. A committed partner helps during the service process.

\section{B. Preparation of Natural Batik and Dye Design Training Activities}

The implementing team of the service program contacted a batik designer and the use of natural batik dyes, namely Mrs. Suprini. He is a batik craftsman in Wonoasri Village in the Jember Regency who successfully developed the industry "Kehati Wonoasri Batik" and several products including using natural dyes. The implementing team of the service program explained to the resource persons about the programs that would be given to partners. The resource person seemed enthusiastic to help make this service program a success. In addition, the speakers also provided input and suggestions regarding the preparations that must be made for the implementation of workshops and training on batik design and the utilization of natural batik dyes. 


\section{Procurement of Tools, Materials and Other Equipment for Workshop Activities and Training of} Batik Designs and Natural Color Utilization

The next activity is the procurement of tools, materials and other equipment needed for batik design workshops and training and the use of natural batik dyes. The tools and materials that have been prepared include batik cloth, yarn, batik canting, batik night, evening pan, night filter, and batik natural coloring. Some of the tools, materials and equipment are used in workshop and training activities (Figure 2).
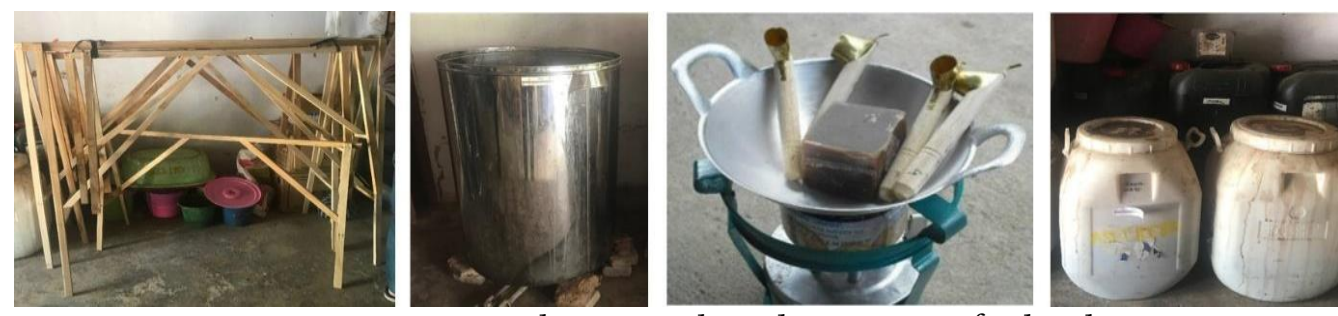

Figure 2. Some tools, materials and equipment for batik

D. Workshop, Training and Mentoring of Natural Batik and Color Design

The workshop was conducted as a form of activity from the coordinating team of the implementation program with the aim of sharing, transferring knowledge (technology transfer), and debriefing partners and members in maintaining commitment in the program strategy for developing the batik creative industry. Each workshop participant gets a module that contains information about the variety of modern batik design motifs. In addition, the module also contains various uses of natural materials as coloring batik along with how to make natural dyes of batik. The workshop was held at the Suling Wetan Village Office which was attended by three partner groups. Workshop, training and mentoring activities were attended by speakers in the field of batik and users of batik natural dyes namely Mrs. Supmini and Mrs. Tutik who were batik artisans of 'Kehati' from Wonoasri Village, Ambulu District, Jember Regency.

Workshop participants can understand the concept of batik creative industry, design attractive batik, manufacture natural dyes and coloring batik using natural dyes. At the end of the workshop the activity was filled with discussion sessions to improve partner understanding. Workshop participants are required to provide opinions, suggestions or criticisms verbally or in writing after the workshop activities are held. During the workshop activities the partners looked very enthusiastic, cooperative and showed a commitment to be solid in collaborating with the implementation team of service activities. Partners also expect the workshop or training activities to be carried out continuously and scheduled. While other participants expect assistance during and after this partnership program is implemented. After the workshop, partners can immediately apply the knowledge and technology in accordance with the modules provided and explanations that have been presented.

Training and mentoring activities began by designing batik on paper using a pencil (Figure 3a). The participants designed batik in accordance with the their concept with the guidance of the speakers. The batik motif chosen in this activity has the theme of nature and the surrounding environment. Some participants designed 
batik with floral motifs and plant parts. After the batik design process, it was followed by scratching the wax coating on batik cloth (Figure 3b). The wac coating ingredients are heated first using medium heat. The melting of the wax coating was taken using a canting tool and then scratched on a white cloth by following the flow of batik motifs that had been designed by each participant.

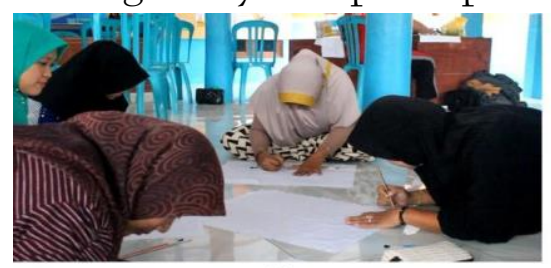

a

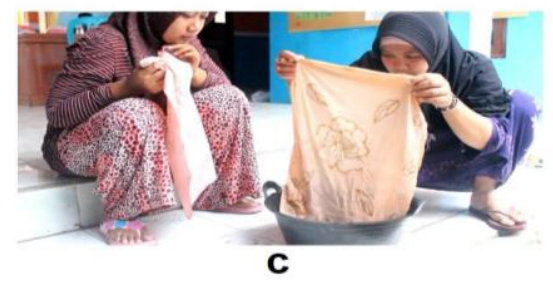

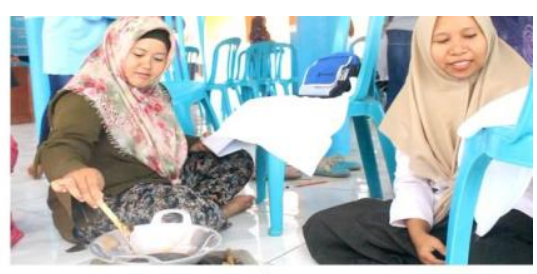

b

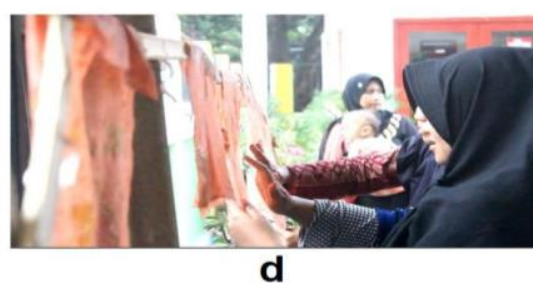

Figure 3. (a) The activity of designing batik motifs on sketch paper, (b) activities scraping the 'night' (wax coating) according to the batik motifs on batik cloth, (c) activities of soaking batik cloth on a solution of boiled young teak leaves, (d) drying batik cloth that has been dyed in natural coloring liquid.

The activity continued by soaking a batik cloth that had been scratched at wax coating in a natural dye solution (Figure 3c). The dye used in this activity is a solution of boiled young teak leaves and then stored as a stock of red dye solution. Natural dyes are not only teak leaves but there are several other ingredients such as noni leaves, shy princess leaves, mangrove leaves, jambal, and jolawe. All these ingredients are very easy to obtain and abundant. So, the way of coloring batik using natural dyes is an environmentally friendly coloring system. In addition, using natural coloring can minimize the cost of buying synthetic dyes which are quite expensive.

The next process is drying the batik cloth(Figure 3d). The drying stage is not recommended directly under the hot sun because it is feared that it can disrupt the binding of the wax coating and natural dyes on the fabric. Air drying will get a brighter coloring result and the binding of natural dyes to the fabric will be stronger. At the end of the activity a photo was taken with the trainees by showing their work. The trainees were satisfied and very happy to get new insights and experiences that they could develop for the batik craft business.

\section{E. Overall Achievement}

In general, the achievement of this strategy has been running well and in according to the planned program. This strategic activities are targeted at the development of the creative batik industry as a driver of the culture in Bondowoso, Suling Wetan Village, Cermee District, Bondowoso Regency. Through this project, the socialization, the workshop, and the training were running well. through this program the batik artist can increase the quality of the batik by using the natural dyes. The batik artist can also 
explore more motif for their batik. The government also provides assistance services for the development of creative industries, and also a roadmap to encourage the tourism sector in Bondowoso Regency.

\section{CONCLUSION}

Based on the results obtained from the partnership service program, it can be concluded that this service activity can add to the public's insight into the strategies for developing the batik creative industry as a driver of the cultural tourism sector in Bondowoso Regency. In addition, this program provided batik tools such as canting, stoves, frying pans, gawangan and pendulum as well as accessories that can be used by partners for catfish cultivation, which in turn can increase the income of surrounding batik partners and craftsmen. The use of natural materials as a natural dye of batik can be a solution that can add value to the creativity of batik products on the market. In addition, the use of natural dyes can reduce the effects of pollution due to the intensive use of synthetic dyes. Integration of the supporting factors of the batik creative industry, namely batik equipment and insight into the use of natural dyes, are the right strategies in developing the batik creative industry that support the development of the cultural tourism sector in Suling Wetan Village, Cermee District, Bondowoso District.

\section{ACKNOWLEDGMENTS}

This dedication activity was funded by the University of Jember DIPA through the Chancellor's Decree No. 12435 / UN25 / LT / 2018 with Assignment Letter 4260 / UN25.3.1 / LT / 2018 Internal Grant of the Partnership Service Program (PPK) Scheme 2018.

\section{REFERENCES}

Bahren, Hidayat, H. N., Sudarmoko, Setyaka, V. 2014. Industri Kreatif Berbasis Potensi Seni Dan Sosial Sudaya di Sumatera Barat. Jurnal Ekspresi Seni. 16(1): 133 - 155. https://journal.isi-padangpanjang.ac.id/index.php/Ekspresi/article/view/24

Damayanti, M. dan Latifah. 2015. Strategi Kota Pekalongan Dalam Pengembanagan Wisata Kreatif Berbasis Industri Batik. Jurnal Pengembangan Kota. 3(2): 100 - 111. https://ejournal2.undip.ac.id/index.php/jpk/article/view/189

Departemen Perdagangan Republik Indonesia. 2009. Studi Industri Kreatif Indonesia. Jakarta: Depdag RI. https://www.academia.edu/27579956/Buku-Studi-danPengembangan-Ekonomi-Kreatif-Indonesia.pdf

Diana, P., Suwena I. K., Wijaya, N. M. S. 2017. Peran Dan Pengembangan Iindustri Kreatif Dalam Mendukung Pariwisata di Desa Mas dan Desa Peliatan Ubud. 
$\begin{array}{llllll}\text { Jurnal Analisis } & \text { Pariwisata. } & 7(2) . & 84 & - & 92 .\end{array}$ https:/ojs.unud.ac.id/index.php/jap/article/view/36485

Fitriana, A, N., Noor, I., Hayat, A. 2014. Pengembangan Industri Kreatif Di Kota Batu (Studi Tentang Industri Kreatif Sektor Kerajinan Di Kota Batu). Jurnal $\begin{array}{llllll}\text { Administrasi } & \text { Publik. } & 2(2): & 281 & - & 286 .\end{array}$ http://administrasipublik.studentjournal.ub.ac.id/index.php/jap/article/view/371

Hartini, S. 2012. Peran Inovasi: Pengembangan Kualitas Produk Dan Kinerja Bisnis. Jurnal Manajemen dan Kewirausahaan. 14(1): 82 - 88. http://jurnalmanajemen.petra.ac.id/index.php/man/article/view/18375

Khoiroh, S., M. 2017. Optimasi Pengembangan Kampung Industri Batik Tulis Daerah Berdasarkan Mapping Value Chain. Prosiding Seminar dan Konferensi Nasional IDEC. $125 \quad$ - $135 . \quad$ https:/idec.ft.uns.ac.id/wpcontent/uploads/2017/11/Prosiding2017_ID025.pdf

Lusianti, L. P. dan Rani, F. 2012. Model Diplomasi Indonesia Terhadap UNESCO Dalam Mematenkan Batik Sebagai Budaya Indonesia Tahun 2009. Jurnal Tradisional. 3(2) : 1 - 19. https://ejournal.unri.ac.id/index.php/JTS/article/view/72

Mangifera, L. 2016. Pengembangan Industri Kreatif Produk Batik Tulis Melalui Value Chain Analysis. The $3^{\text {rd }}$ University Reserach Colloqoium. 157 - 166. https://publikasiilmiah.ums.ac.id/.../14.\%20Liana\%20Mangifera.pdf

Nurainun, Heriyana, Rasyimah. 2008. Analisis Industri Batik Di Indonesia. Fokus $\begin{array}{lllll}\text { Ekonomi. } & 7(3): & 2124 & - & 135 .\end{array}$ https://www.unisbank.ac.id/ojs/index.php/fe2/article/view/1647

Prasetyo, P. E. 2016. Dampak Kebijakan Peningkatan Techno-Ekonomy Pada Industri Tekstil Sebagai Upaya Peningkatan Produktivitas Dan Daya Saing Bangsa. Prosiding Seminar Multidisiplin Ilmu Unisbank. 820 - 828. https://www.unisbank.ac.id/ojs/index.php/sendi_u/article/view/4272

Rini, E. P., Pratiwi, R. N., Adiono, R. 2015. Strategi Menciptakan Iklim UKM Pada Industri Kreatif Batik Tulis (Studi pada Dinas Koperasi, Industri, Dan Perdagangan Kabupaten Kediri). Jurnal Administrasi Publik. 3(12): 2012 - 2027. http://administrasipublik.studentjournal.ub.ac.id/index.php/jap/article/view/108 8

Salman, D. 2010. Rethinking Of Cities, Culture And Tourism Within A Creative Perspective. PASOS. 8(3): 06-16. http://www.pasosonline.org/Publicados/8310special/PSO310_01.pdf

Sari, N. 2018. Pengembangan Ekonomi Kreatif Bidang Kerajinan Tradisional Jambi (Studi Kasus : Rengke Suku Anak Dalam). Jurnal Menejemen Terapan dan Keuangan.

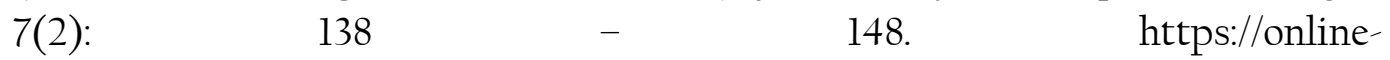
journal.unja.ac.id/index.php/mankeu/article/view/5462 